\title{
Toxoplasma gondii survey in cats from two environments of the city of Rio de Janeiro, Brazil by Modified Agglutination Test on sera and filter-paper
}

\author{
Paula F. Bolais ${ }^{1,2^{*}}$, Philippe Vignoles ${ }^{1}$, Pamela F. Pereira ${ }^{2}$, Rafael Keim ${ }^{3}$, Abdelkrim Aroussi ${ }^{1}$, Khadja Ismail ${ }^{1}$,
} Marie-Laure Dardé ${ }^{1}$, Maria Regina Amendoeira ${ }^{2}$ and Aurélien Mercier ${ }^{1}$

\begin{abstract}
Background: Toxoplasma gondii is a protozoan with a worldwide distribution, in warm-blood animals, including humans. Local conditions and environmental disturbances may influence transmission dynamics of a zoonotic agent. This study evaluates the epidemiology of $T$. gondii based on toxoplasmosis prevalence in two populations of cats living in distinct urbanization conditions in Rio de Janeiro, Brazil.

Methods: Among 372 domestic cats sampled, 265 were from a public shelter located downtown Rio and 107 from a relatively preserved wild environment in a residential area. Sera and eluates from dried blood spots were tested for detection of IgG antibodies against T. gondii by modified agglutination test (MAT).

Results: Antibodies to T. gondii were detected in 32/265 (12.08\%) animals from the public shelter and in 4/107 (3.74\%) cats from the residential area. Identical results were observed for sera and eluates.

Conclusions: Filter paper provides a reliable accurate alternative storage option when conditions of sample collection and transportation in the field are unfavorable. The significantly lower prevalence in the residential area is discussed in terms of environmental, biological and behavioral features.
\end{abstract}

Keywords: Toxoplasma gondii, Cats, Serology, Modified agglutination test, Filter paper, Eco-epidemiology, Brazil

\section{Background}

Toxoplasma gondii is a protozoan with a successful worldwide distribution and a widespread presence in warm-blood animals, including humans [1]. These characteristics have encouraged numerous studies in order to better understand its biology, genetics and transmission dynamics. The lifecycle of Toxoplasma gondii comprises three infective stages: the invasive tachyzoites, the encysted bradyzoites and the environmental sporozoites protected by the oocyst wall. Acting as definitive hosts, either domestic cats or wild felids play the major role in spreading the parasite by shedding

\footnotetext{
* Correspondence: pfbolais@yahoo.com.br

${ }^{1}$ Univ. Limoges, INSERM UMR-S 1094 Tropical Neuroepidemiology, Institute of Neuroepidemiology and Tropical Neurology, 2 Rue du Dr. Marcland, Limoges 87025, France

${ }^{2}$ Toxoplasmosis and other Protozoosis Laboratory of Oswaldo Cruz Institute, Av. Brasil 4365, Rio de Janeiro 21045-900, Brazil

Full list of author information is available at the end of the article
}

oocysts in faeces [2]. Contaminated soil, water courses and agricultural crops become the source of infection for domestic or wild animals and livestock. For humans, the most important routes of transmission are through ingestion of undercooked meat with cysts, poorly washed vegetables and water or soil contaminated with oocysts $[3,4]$.

Globally, the prevalence of human Toxoplasma infection varies significantly. It ranges from less than $10 \%$ in Korea [5] to over $80 \%$ in Brazil [6]. These differences are attributed to risk factors that may vary between regions, such as the type of food, the cooking mode, adequate water treatment and intensity of environmental exposure [4, 6-10]. Although infection with $T$. gondii is generally asymptomatic, human infection in South America, mainly in Brazil, may lead to neurological complications and ocular lesions, probably due to the genetic difference in these virulent strains and poor host adaptation 
[11]. With significant serological prevalence of T. gondii in the Brazilian general population (up to 80\%) [6], the national government faces a large public health burden in view of many cases of congenital toxoplasmosis: 6 to 9/10,000 births in Brazil $[12,13]$ compared to 3.3/10,000 births in France [14].

In veterinary medicine worldwide, $T$. gondii is a major cause of abortion in sheep and goats [15]. Clinical toxoplasmosis and fatal cases of the disease have been reported in New World monkeys [16], squirrels, New World porcupines [17], pigs [18], birds [19-22] and marine mammals [23-25]. Taking into account only recent studies using the same serological test (modified agglutination test) in animal samples from the Brazilian environment, it is possible to observe that, regardless of their habitats, several animal species have a high prevalence of $T$. gondii antibodies: up to 87\% (55/63) of domestic cats [26] (Table 1), 86\% (99/115) of pigs [27], $53.3 \%(202 / 379)$ of sheep [28], 75\% (48/64) of capybaras [29], 60\% $(10 / 18 ; 60 / 37)$ of pacas [30, 31], 85.3\% (99/116) of non-human primates [32], 79.7\% (157/197) of cattle egrets [33] and 86.3\% (82/96) of Amazon river dolphins [34]. These data, in addition to those concerning the high prevalence in the Brazilian human population, suggest that the country has a high environmental contamination.

Previous studies have demonstrated that local conditions and environmental disturbances may influence the genetic composition of a zoonotic agent [35] or its transmission dynamics [36]. Our study aimed to verify if environmental differences were likely to influence $T$. gondii epidemiology in two populations of cats living in quite distinct conditions in the city of Rio de Janeiro. This will help us to better understand the causal relationships between urban areas, biological diversity and $T$. gondii prevalence and then provide useful information for decision-making in public health.

Furthermore, we verified the accuracy of the serological testing with the use of samples stored on filter papers, in

Table 1 Studies conducted in Brazil on Toxoplasma seroprevalence in cat populations using the MAT technique

\begin{tabular}{lllll}
\hline Location $^{\text {a }}$ & $\begin{array}{l}\text { \% positive } \\
\text { (No. positive/total no.) }\end{array}$ & $\begin{array}{l}\text { Cut-off } \\
\text { titer }\end{array}$ & Cat life style & Reference \\
\hline Pernambuco & $66.6(32 / 48)$ & $1: 25$ & free-roaming & {$[33]$} \\
Pernambuco & $44.4(20 / 45)$ & $1: 25$ & owned & {$[33]$} \\
Rondônia & $87.3(55 / 63)$ & $1: 25$ & free-roaming & {$[26]$} \\
São Paulo & $35.4(84 / 237)$ & $1: 25$ & free-roaming & {$[74]$} \\
Paraná & $84.4(49 / 58)$ & $1: 20$ & owned & {$[75]$} \\
São Paulo & $19(19 / 100)$ & $1: 16$ & Nl & {$[76]$} \\
São Paulo & $26.3(132 / 502)$ & $1: 20$ & free-roaming & {$[76]$} \\
\hline
\end{tabular}

NI not informed

${ }^{\text {a }}$ State of Brazil addition to the classic MAT method on serum. Collection cards have been used for epidemiological surveys in wildlife [37, 38], and more specifically for screening of $T$. gondii antibodies in peccaries, brocket deer and lowland tapir [39], as well as in wild goose [40], red foxes [41], wild waterfowl [42], beavers [43], and commensal rodents [44]. Indeed, this is the first time that dried blood spots of cat samples have evaluated as suitable to MAT.

\section{Methods}

\section{Study area}

The municipality of Rio de Janeiro is located in a humid tropical marine-plain climate in southeast Brazil. It has an area of about 122,000 hectares and a population of over 6 million people [45]. The demographic density in city districts varies significantly. Taking this into account, two very different places in the city of Rio de Janeiro were chosen for sampling: a public cat shelter located downtown and a private residential area situated in a seaside district (Fig. 1). Both sites are currently classified as urban areas. Despite this classification, in the shelter area urbanization is older and more intense than in the residential district.

The municipal animal shelter (MS) is located downtown. It has an area of $9300 \mathrm{~m}^{2}$, harbors 300 cats, and provides full-time veterinary monitoring and commercial cat food. Colonization of the country began in the seventeenth century in this part of the city. Urbanization occurred gradually until the mid-nineteenth century when settlements grew increasingly faster. This triggered significant urbanization of the city resulting in drainage, embankment and landfill of its original swamps and marshes, and transformed its landscape to its current condition (99\% of its territory is classified as urbanized) with a demographic density of 100 people per hectare [46] (Table 2).

The residential seaside district is less than $20 \mathrm{~km}$ from downtown, and has a demographic density of less than 50 people per hectare [47]. It is composed of barrier islands (sandy strips) separated from the mainland by a wide lagoon complex. Until recently, this was a wellpreserved region, being submitted to a systematic urbanization from the 1970s. Currently, only $55 \%$ of its area is classified as urbanized. The private residential district (RD), where the population of free-range cats sampled for this study lives, is located in a peninsular region. It has an area of $780,000 \mathrm{~m}^{2}$, of which $18 \%$ are buildings whose construction took place in the 2000s. They are surrounded by a lagoon with high salinity and $1.4 \mathrm{~m}$ depth maximum, and water temperatures range from 17 to $34{ }^{\circ} \mathrm{C}$ according to the season of the year. The lagoon preserves in its surroundings a wide area of mangroves, and is contiguous with areas of preserved sandbanks and flooded fields. The mangroves are home 


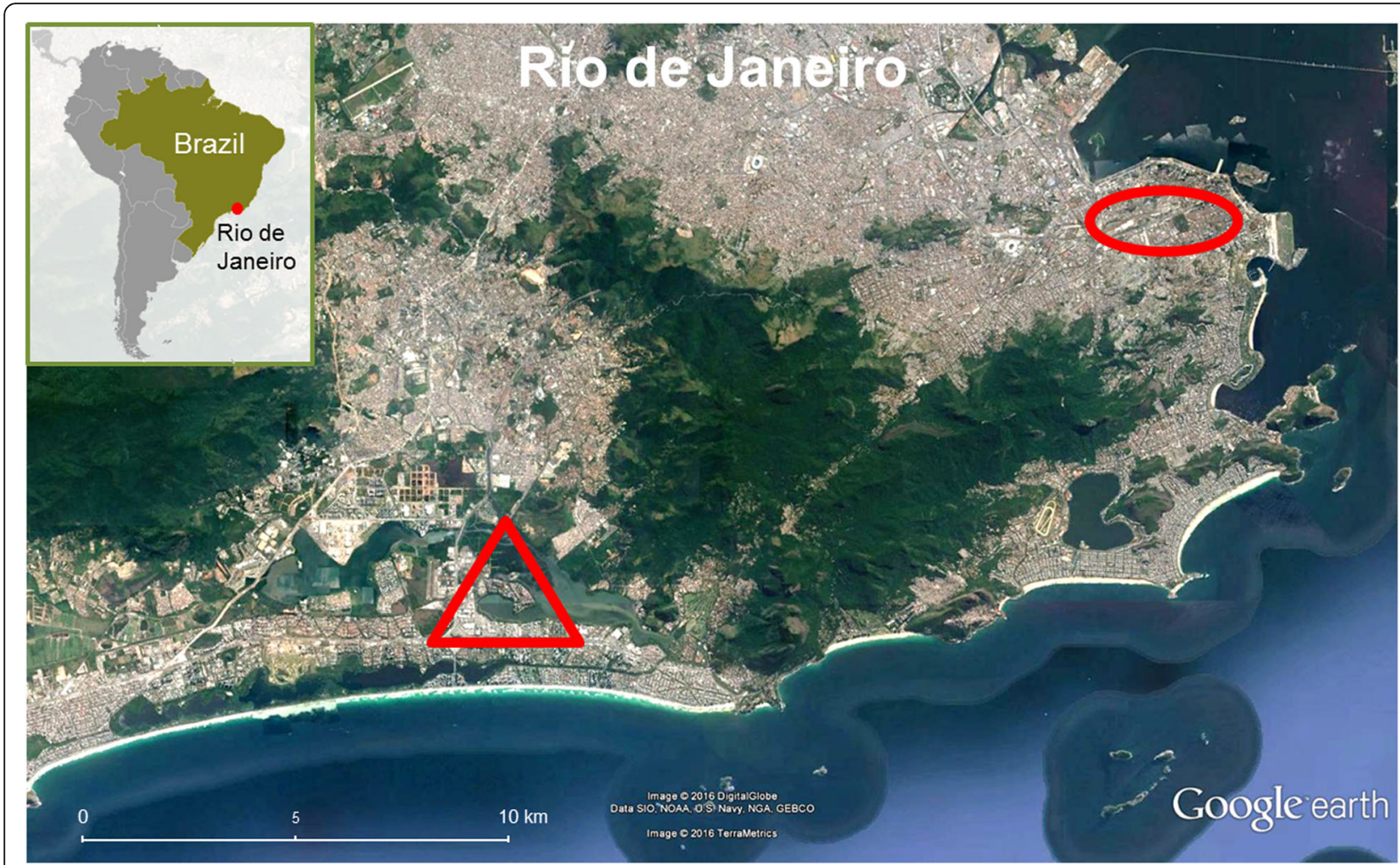

Fig. 1 The city of Rio de Janeiro and sample collection areas. The municipal shelter is located within the red circular area, and the residential district corresponds to the red triangular area. Map: Adapted from the Central Intelligence Agency Web site [77] and GOOGLE EARTH - Data SIO, NOAA, U.S. Navy, NGA, GEBCO, image® 2016 DigitalGlobe/TerraMetrics

Table 2 Environmental characteristics of sample collection areas and living conditions of the corresponding cat populations

\begin{tabular}{|c|c|c|}
\hline \multirow[t]{2}{*}{ Features $^{a}$} & \multicolumn{2}{|c|}{ Sample collection areas } \\
\hline & Municipal shelter & Residential district \\
\hline Living space & shelter & $\begin{array}{l}\text { private residential } \\
\text { district }\end{array}$ \\
\hline Life style & sheltered & $\begin{array}{l}\text { free-roaming } \\
\text { (stray and feral) }\end{array}$ \\
\hline Food habits & mostly kibbles & mostly prey \\
\hline Area $\left(m^{2}\right)$ & 9,300 & 780,000 \\
\hline Cat density ( $\mathrm{m}^{2}$ per cat) & 31 & 3,587 \\
\hline Biodiversity & poor & rich \\
\hline Climate & humid tropical & humid subtropical \\
\hline Annual rainfall index $(\mathrm{mm})^{\mathrm{b}}$ & 512.2 & 966.2 \\
\hline Landscape & $\begin{array}{l}\text { embankment, } \\
\text { landfill }\end{array}$ & sandbank, mangroves \\
\hline District urbanization (\%) & 99 & 55 \\
\hline $\begin{array}{l}\text { District density (people } \\
\text { per hectare) }\end{array}$ & up to 100 & up to 50 \\
\hline
\end{tabular}

${ }^{a}$ Cat population data were provided by the Special Office of Defense and Promotion of Animals of the City of Rio de Janeiro and by Quatro Elementos Veterinary Medicine and Environmental consulting. The climatic and demographic data are available at http://www.armazemdedados.rio.rj.gov.br/ ${ }^{\mathrm{b}}$ Data from the 2014 report of Alerta-Rio [69] to high biodiversity, with fish stocks, crustaceans and mollusks. These provide an abundant food supply which attracts numerous birds and mammals (8 species of wild mammals, 32 of birds and 4 of reptiles) (Rafael Keim, pers. comm.). This wild fauna shares the territory with about 14,000 human inhabitants and their pets and an estimated population of 200 stray cats. This estimation, made by a local veterinarian, was obtained by counting all the cats in random samples of district sub-regions and extrapolating the count to the whole district.

\section{Sample collection}

In 2014 and 2015, a total of 372 cats from these two different populations of Rio de Janeiro were sampled for this study: 265 from the public cat shelter located in city center which gathered cats from a surrounding public square and 107 from the private residential area situated in the seaside district. Each animal from both populations had been previously identified with subcutaneous electronic microchips (AnimallTAG ${ }^{\circ}$ ) and had individual information recorded (sex, morphologically estimated age, reproductive status). Their blood was collected by puncture of the cephalic vein and four to six drops of the collected fluid were used to soak two circles of a Whatman ${ }^{\mathrm{mm}} 903$ specimen collection paper (Whatman ${ }^{\mathrm{mm}}$ 
GE Healthcare Life Sciences, Florham Park, USA). Remaining collected blood was stored in collection tubes without anticoagulant to obtain serum. Identified collection cards were left at room temperature for $4 \mathrm{~h}$ to complete drying and then sealed in plastic bags to be stored at room temperature for 3 months, and then at $4{ }^{\circ} \mathrm{C}$ for another 3 months before testing.

\section{Serological examination}

The elution protocol and MAT serological technique for filter paper were adapted from Mercier et al. [44]. At first, for dry blood spot elution, two spots $(5 \mathrm{~mm}$ diameter each) were punched from Whatman ${ }^{\mathrm{rm}} 903$ collection cards and placed in flat bottom microplates. Then, to yield a 1:8 dilution of serum, they were agitated overnight in $80 \mu \mathrm{l}$ phosphate buffer saline $\mathrm{pH} 7.2$ (BioMérieux, Marcy l'Etoile, France) at 400× rpm at room temperature. Sera from ordinary collection tubes and those obtained from eluted dried spots were tested for IgG antibodies against $T$. gondii by MAT. Samples were screened at four serial dilutions (1:20, 1:40, 1:100 and 1:800) with a cut-off dilution at 1:20.

The current study applied the MAT protocol of Desmonts \& Remington [48]. We ensured that the final concentration of 2-mercaptoethanol for each dilution was $0.05 \mathrm{M}$ after antigen addition. Serological controls for the filter paper adapted MAT were fresh blood from seronegative and experimentally infected seropositive Swiss mice (Mus musculus, Janvier, Le Genest-Saint-Isle, France) [44]. Although these control sera were not cat sera, they represent a quality control for each series of serological tests. Mouse blood with T. gondii antibodies were spotted onto a $5 \mathrm{~mm}$ diameter circle of filter paper, allowed to dry and stored in the same conditions as the samples.

\section{Statistical analysis}

Statistical analyses were performed using logistic regression and Fisher's exact test. Results were considered significant when $P<0.05$. Statistical analyses were performed using the $\mathrm{R} \times 64.3 .3 .0$ software [49] with the two-tailed significance level of $5 \%$.

\section{Results}

Samples stored on filter paper showed the same qualitative results for MAT as sera from collection tubes. Positive samples (36) showed high titers $(\geq 1: 800)$ with both techniques, except for 3 cases which showed discordance between titers obtained with MAT on serum or dried blood spots (800/20, 100/40 and 100/800, respectively). Antibodies to $T$. gondii were detected in 4/107 (3.74\%) stray cats from the private residential district $(\mathrm{RD})$ and in $32 / 265$ (12.08\%) animals from the municipal shelter (MS).

The prevalence difference between the two localities was significant with both statistical tests $(P<0.01$ with $C I$ of $95 \%$ ). Logistic regression quantified the difference in infection risk between the two localities. It showed that the risk of infection for cats was 3.54 times higher in MS compared to RD with a 95\% confidence interval from 1.22 to 10.26 . $(P<0.05)$. No statistically significant association regarding the age or sex of animals was observed (Table 3 ). Regarding the reproductive status, the association with prevalence was not statistically significant if we consider the whole population of cats, but became significant if we consider only RD cat population $(P=0.048)$.

\section{Discussion}

This is the first time that MAT results from cat blood samples stored on filter papers were compared to those from sera samples. In fact, it was expected that MAT would have been less sensitive when performed on filter paper samples due to loss of detectable antibodies during storage and elution. Nevertheless, the differences observed for three sera did not change the prevalence results and may be due to the high antibody levels and short duration of sample storage $[39,44]$. It certifies the accuracy of dried blood samples of cats tested by MAT and confirms this technique as a reliable alternative storage method.

Moreover, filter papers proved to be appropriate for the unfavorable conditions of sample collection from feral cats in which restraint requires speed by the health staff. Taking this into account, the possibility of testing with only a few drops of blood without sedation or animal stress provides us the necessary speed to ensure safe and effective sample collection. Moreover, it corroborates

Table 3 MAT results in the different cat populations and risk factors

\begin{tabular}{|c|c|c|c|c|c|c|c|c|}
\hline \multirow[t]{2}{*}{ Location } & \multirow[t]{2}{*}{ Entire population } & \multicolumn{2}{|l|}{ Gender $^{a}$} & \multicolumn{3}{|c|}{ Reproductive status } & \multicolumn{2}{|l|}{ Age class } \\
\hline & & Female & Male & Neutered & Not neutered & $\mathrm{NI}$ & $\overline{\text { Adult }}$ & Juvenile \\
\hline$\overline{M S}$ & $\begin{array}{l}32 / 265(12.08) \\
{[8.40-16.60]}\end{array}$ & $\begin{array}{l}\text { 20/163 (12.27) } \\
{[7.65-18.30]}\end{array}$ & $\begin{array}{l}12 / 101(11.88) \\
{[6.20-19.80]}\end{array}$ & $\begin{array}{l}\text { 23/196 (11.73) } \\
{[7.58-17.10]}\end{array}$ & $\begin{array}{l}1 / 4(25) \\
{[0.63-80.60]}\end{array}$ & $\begin{array}{l}8 / 65(12.31) \\
{[5.40-22.80]}\end{array}$ & $\begin{array}{l}32 / 257(12.45) \\
{[8.67-17.10]}\end{array}$ & $\begin{array}{l}0 / 8(0) \\
{[0.00,36.90]}\end{array}$ \\
\hline $\mathrm{RD}$ & $\begin{array}{l}4 / 107(3.74) \\
{[1.02-9.30]}\end{array}$ & $\begin{array}{l}3 / 68(4.41) \\
{[0.92-12.40]}\end{array}$ & $\begin{array}{l}1 / 39(2.56) \\
{[0.06-13.50]}\end{array}$ & $\begin{array}{l}4 / 42(9.52) \\
{[2.65-22.60]}\end{array}$ & $\begin{array}{l}0 / 43(0) \\
{[0.00-8.20]}\end{array}$ & $\begin{array}{l}0 / 22(0) \\
{[0.00-15.40]}\end{array}$ & $\begin{array}{l}3 / 91(3.30) \\
{[0.69-9.30]}\end{array}$ & $\begin{array}{l}1 / 16(6.25) \\
{[0.16-30.20}\end{array}$ \\
\hline$P$-value & $<0.01$ & ns & ns & ns & ns & ns & $<0.01$ & ns \\
\hline
\end{tabular}

MS Municipal shelter, $R D$ Residential district, $N I$ the reproductive status was not identified in clinical examination, $n s$ not significant ${ }^{a}$ Sex could not be determined for one cat

Results are expressed as number of positive cats/total number of cats (\% positive) [95\% confidence interval] 
advantages highlighted by other studies, such as the impossibility of frozen or refrigerated storage of sera [40,42]. It is also convenient if sample transport is subject to unfavorable conditions, high cost or restrictions, as in remote and isolated areas [38, 39]. It should be noted that our samples were stored up to 6 months, first at room temperature, and then at $4{ }^{\circ} \mathrm{C}$, without silica gel. Nogami et al. [50] already noted a successful long-term preservation (up to 12 months) of feline anti-T. gondii antibody activity on filter paper strips stored either at $25^{\circ} \mathrm{C}$ or $4{ }^{\circ} \mathrm{C}$, but preservation was improved when filter papers were stored with silica gel.

Others studies concerning $T$. gondii infection in cats in the region of Rio de Janeiro used a different serological test making it difficult to compare results [51-54]. However, the prevalence of $T$. gondii antibodies in cats from this study seemed to be lower than those found in other populations in Brazil with the use of MAT (Table 1). Despite the use of the same serological test in all these studies, a remarkable range of results was observed. These different results are probably due to sample collection from markedly different environments.

There are possible biases to explain the significantly higher seroprevalence in MS compared to RD. First, given the difficulties of trapping animals, sampling of $50 \%$ of RD estimated population probably consisted of more stray cats than feral ones. Thus, the data not included in the study may have caused an underestimation of prevalence due to different feeding habits. The wild cats have a diet based mostly on hunting, while more sociable cats are used to being fed with kibbles occasionally provided by residents. Supplement feeding in urban stray cat populations may reduce cat exposure to toxoplasmosis [36]. Secondly, cats of RD were not neutered systematically, as in MS population, so an excessive number of kittens (15\%) took part in sampling at this location. As the opportunity to acquire Toxoplasma infection through predation is lower for kittens, this could have explained the lower prevalence in RD cats. Nevertheless, no statistically significant association regarding the age of animals was observed. When kitten samples were removed for new statistical analysis, there remained a significant difference between the two areas $(P=0.006)$ (data not shown).

Usual risk factors for Toxoplasma infection associated with cat populations are stray vs owned cats, sex, or sterilization as these factors may have an influence on predation and social behavior [2]. These risk factors were not significant in our study. Sheltered cats may be considered as owned animals (restricted area, manufactured food and human interaction). Results from this study diverged from those of other teams that suggested that stray cats generally have a higher prevalence than owned ones [33, 55-59]. No significant association was observed regarding sex and $T$. gondii infection in cats from both populations. This result differs from those from Afonso et al. [60] which suggested that males are more infected than females when more prey is caught due to male predation efficiency. Once more, these findings lead us to suspect that the non-exhaustive sampling at $\mathrm{RD}$ could have biased data since males generally are more feral and difficult to trap compared to females. Since virtually all cats were neutered at MS, the association of reproductive status and risk factor was verified based only on the RD population. Similar to results reported by Afonso et al. [56], there was a positive correlation between $T$. gondii infection and sterilization within the RD cat population. It would be prudent to acquire additional samples to confirm this association. Neutered cats are more social and less wandering. This characteristic may have a protective effect since roaming may increase risk of infection by predation [36]. However, the increased risk of infection by oocysts may also be considered since social groups share restricted areas and common defecation sites [61, 62].

The positive association of $T$. gondii infection and the location where cats live corroborates the hypothesis that antibody prevalence in cats may vary according to different environments [36, 59]. In locations surveyed in this study, the associated environmental risk factors could be cat density, diversity of prey, and climatic conditions. Concerning the density risk factor, it is quite discrepant: $31 \mathrm{~m}^{2} /$ cat at $\mathrm{MS}$ and $3587 \mathrm{~m}^{2} /$ cat at RD. Considering that a cat can excrete millions of oocysts during early infection [2], we can deduce that high densities of cats in the downtown area must have contributed to local environmental contamination favoring oocyst transmission to intermediate hosts or between cats $[36,63]$. In contrast, low densities may also contribute to infection, if predation rate is favorable [36]. At RD, we observed a low density of cats and a high biodiversity featuring abundance of prey. Different prey species have different infection rates according to their susceptibility, exposure and lifespan [60]. Present at RD, Brazilian guinea pigs are possibly one of the major food source for cats and other local carnivores. Little is known about natural infection by $T$. gondii for this species. Pelecaniformes (herons, egrets and ibis) and Capybaras have significant prevalence of $T$. gondii antibodies in other Brazilian environments [29, 33, 64, 65]. But even if they are plentiful at RD, they are improbable prey for feral cats. Another hypothesis that should be considered is the significant presence of crustaceans and fish at RD mangroves which serve as an estuary. This abundant and easy food source for local feral cats may decrease the risk of infection as they are not intermediate hosts for T. gondii [2].

Climatic factors influence the risk of infection in cats and their prey $[56,63,66,67]$. Oocyst survival is well known to depend on physical and climatic conditions 
[56, 68]. Despite the short distance between MS and RD, factors such as the proximity to the sea, mountain ranges and vegetation determine climatic variations between these two close areas. RD is in a humid subtropical region of Rio de Janeiro. In the winter, moist winds from the sea are buffeted by mountains, which increase the amount of rainfall. This region usually receives almost twice the volume of rain compared to the downtown district of MS [69]. In the current study, the rainfall index seems to have a negative association with $T$. gondii infection, which differs from that observed by Afonso et al. [56]. In RD, local high precipitation and mangroves may favor runoff and vegetation uptake of oocysts $[24,70-73]$.

\section{Conclusion}

In conclusion, this study suggests that differences in environmental features and human deterioration of habitats may play a role in cat infection levels probably through soil contamination by $T$. gondii and cat feeding behavior. The high local densities of cats in public shelters provide a high concentration of oocysts in areas close to humans. Further studies in tropical environments are necessary to elucidate this question. These studies may be facilitated by using dried blood spots on filter paper which was shown to be an advantageous approach for serological surveys of $T$. gondii infection in cats.

\section{Abbreviations}

DVM: Doctor of veterinary medicine; MAT: Modified agglutination test; MS: Municipal animal shelter; RD: Private residential district

\section{Acknowledgements}

We would like to thank the National Council of Scientific and Technologic Development for the scholarship of P.F.B., as well as Juan Fidel Bencomo from Vital Brasil Institute. We also thank the Department of Animal Promotion and Defense of the municipality of Rio de Janeiro and ASSAPE association. We are grateful to William Távora Chaves and all those who participated in the sampling. We would like to thank Dr. Jeanne Cook-Moreau (Université de Limoges) for critical reading of the manuscript and for correcting the English.

\section{Funding}

This research was supported by INSERM UMR-S 1094 Institute of Neurologica Epidemiology and Tropical Neurology, and by the Brazilian National Council of Scientific and Technologic Development.

\section{Availability of data and materials}

Not applicable.

\section{Authors' contributions}

PFB conceived the study, carried out sampling and serology experiments and drafted the manuscript. PV participated in statistical analysis and manuscript revision. PFP and RK sampled blood specimens from animals and were responsible for acquisition of data. AA and $\mathrm{KI}$ contributed to serology experiments. MRA helped in study implementation and has been involved in critically revising the manuscript for major intellectual content. MLD and AM conceived and designed the study and critically revised manuscript. All authors read and approved the final manuscript.

\section{Competing interests}

The authors declare that they have no competing interests.
Consent for publication

Not applicable.

\section{Ethics approval and consent to participate}

This research was developed with the approval of Limoges University ethics committee number 87.797, as well as the Oswaldo Cruz Foundation (Fiocruz) Ethics Committee on the Use of Animals under the record LW-53/13, and with the local authority authorization.

\section{Author details}

'Univ. Limoges, INSERM UMR-S 1094 Tropical Neuroepidemiology, Institute of Neuroepidemiology and Tropical Neurology, 2 Rue du Dr. Marcland, Limoges 87025, France. ${ }^{2}$ Toxoplasmosis and other Protozoosis Laboratory of Oswaldo Cruz Institute, Av. Brasil 4365, Rio de Janeiro 21045-900, Brazil. ${ }^{3}$ Quatro Elementos Veterinary Medicine and Environmental consulting, Rua Coronel Moreira Cesar, 211 Bl. 2/502, Niteroi 24.230-052, Brazil.

Received: 19 October 2016 Accepted: 7 February 2017

Published online: 17 February 2017

\section{References}

1. Robert-Gangneux F, Dardé ML. Epidemiology of and diagnostic strategies for toxoplasmosis. Clin Microbiol Rev. 2012;25:264-96.

2. Dubey JP. Toxoplasmosis of animals and humans. 2nd ed. Boca Raton: CRC Press; 2010.

3. Jones JL, Kruszon-Moran D, Rivera HN, Price C, Wilkins PP. Toxoplasma gondii seroprevalence in the United States 2009-2010 and comparison with the past two decades. Am J Trop Med Hyg. 2014;90:1135-9.

4. Cook AJC, Holliman R, Gilbert RE, Buffolano W, Zufferey J, Petersen E, et al. Sources of Toxoplasma infection in pregnant women: European multicentre case-control study. BMJ. 2000:321:142-7.

5. Song KJ, Shin JC, Shin HJ, Nam HW. Seroprevalence of toxoplasmosis in Korean pregnant women. Korean J Parasitol. 2005;43:69-71.

6. Pappas G, Roussos N, Falagas ME. Toxoplasmosis snapshots: global status of Toxoplasma gondii seroprevalence and implications for pregnancy and congenital toxoplasmosis. Int J Parasitol. 2009;39:1385-94.

7. Bóia MN, Carvalho-Costa FA, Sodré FC, Pinto GMT, Amendoeira MRR. Seroprevalence of Toxoplasma gondii infection among Indian people living in lauareté, São Gabriel da Cachoeira, Amazonas, Brazil. Rev Inst Med Trop Sao Paulo. 2008;50:17-20.

8. Sobral CA, Amendoeira MRR, Teva A, Patel BN, Klein CH. Seroprevalence of infection with Toxoplasma gondii in indigenous Brazilian populations. Am J Trop Med Hyg. 2005;72:37-41.

9. Spalding SM, Amendoeira MRR, Klein CH, Ribeiro LC. Serological screening and toxoplasmosis exposure factors among pregnant women in South of Brazil. Rev Soc Bras Med Trop. 2005;38:173-7.

10. Bahia-Oliveira LMG, Jones JL, Azevedo-Silva J, Alves CCF, Oréfice F, Addiss DG. Highly endemic, waterborne toxoplasmosis in north Rio de Janeiro state, Brazil. Emerg Infect Dis J. 2003;9:55-62.

11. Ajzenberg D. Unresolved questions about the most successful known parasite. Expert Rev Anti-Infect Ther. 2011;9:169-71.

12. Varella IS, Cant ICT, Santos BR, Coppini AZ, Argondizzo LC, Tonin C. Wagner MB. Prevalence of acute toxoplasmosis infection among 41,112 pregnant women and the mother-to-child transmission rate in a public hospital in South Brazil. Mem Inst Oswaldo Cruz. 2009:104:383-8.

13. Bischoff AR, Friedrich L, Cattan JM, Uberti FA. Incidence of symptomatic congenital toxoplasmosis during ten years in a Brazilian Hospital. Pediatr Infect Dis J. 2016;35:1313-6.

14. Villena I, Ancelle T, Delmas C, Garcia P, Brezin AP, Thulliez P, et al. Congenital toxoplasmosis in France in 2007: first results from a national surveillance system. Eurosurv. 2010;15:19600.

15. Tenter AM, Heckeroth AR, Weiss LM. Toxoplasma gondii: from animals to humans. Int J Parasitol. 2000;30:1217-58.

16. Antoniassi NA, Boabaid FM, Souza RL, Nakazato L, Pimentel MF, Filho JO Colodel EM. Granulomatous meningoencephalitis due to Toxoplasma gondii in a black-headed night monkey (Aotus nigriceps). J Zoo Wildl Med. 2011;42:118-20

17. Fayyad A, Kummerfeld M, Davina I, Wohlsein P, Beineke A, Baumgärtner W, Puff C. Fatal systemic Toxoplasma gondii infection in a red squirrel (Sciurus vulgaris), a swinhoe's striped squirrel (Tamiops swinhoei) and a New World porcupine (Erethizontidae sp.). J Comp Pathol. 2016;154:263-7. 
18. da Silva JML L. Sobre um caso de toxoplasmose espontanea em suinos. Arq Esc Sup Vet. 1959;12:425-8.

19. Casagrande RA, Pena HF, Cabral AD, Rolim VM, de Oliveira LG, Boabaid FM, et al. Fatal systemic toxoplasmosis in valley quail (Callipepla californica). Int J Parasitol Parasites Wildl. 2015;4:264-7.

20. Ferreira Jr FC, Donatti RV, Marques MVR, Ecco R, Preis IS, Shivaprasad HL, et al. Fatal toxoplasmosis in a vinaceous Amazon parrot (Amazona vinacea). Avian Dis. 2012;56:774-7

21. Dubey JP. A review of toxoplasmosis in wild birds. Vet Parasitol. 2002;106:121-53.

22. Work TM, Massey JG, Lindsay DS, Dubey JP. Toxoplasmosis in three species of native and introduced Hawaiian birds. J Parasitol. 2002;88:1040-2.

23. Thomas NJ, Dubey JP, Lindsay DS, Cole RA, Meteyer CU. Protozoal meningoencephalitis in sea otters (Enhydra lutris): a histopathological and immunohistochemical study of naturally occurring cases. J Comp Pathol. 2007;137:102-21.

24. Miller MA, Gardner IA, Kreuder C, Paradies DM, Worcester KR, Jessup DA, et al. Coastal freshwater runoff is a risk factor for Toxoplasma gondii infection of southern sea otters (Enhydra lutris nereis). Int J Parasitol. 2002:32:997-1006

25. Bandoli JG, Oliveira CB. Toxoplasmose em Sotalia guianensis (Van Beneden, 1863), Cetacea-Delphinidae. Folha Médica. 1997;75:459-68.

26. Cavalcante GT, Aguiar DM, Chiebao D, Dubey JP, Ruiz VLA, Dias RA, et al. Seroprevalence of Toxoplasma gondii antibodies in cats and pigs from rural Western Amazon, Brazil. J Parasitol. 2006;92:863-4.

27. Silva RAMS, Bonassi C, Dalla Costa OA, Morés N. Serosurvey on toxoplasmosis in outdoor pig production systems in the southern region of Brazil - Enquête séro-épidémiologique sur la toxoplasmose dans les systèmes de production porcine de plein air dans la région du sud du Brésil. Rev Elev Med Vet Pays Trop. 2003;56:3-4.

28. Cosendey-KezenLeite RIJ, de Oliveira FCR, Frazão-Teixeira E, Dubey JP, de Souza GN, Ferreira AMR, Lilenbaum W. Occurrence and risk factors associated to Toxoplasma gondii infection in sheep from Rio de Janeiro, Brazil. Trop Anim Health Prod. 2014;46:1463-6.

29. Yai LE, Ragozo AM, Aguiar DM, Damaceno JT, Oliveira LN, Dubey JP, Gennari SM. Isolation of Toxoplasma gondii from capybaras (Hydrochaeris hydrochaeris) from São Paulo state, Brazil. J Parasitol. 2008:94:1060-3.

30. Minervino AHH, Soares HS, Barrêto-Júnior RA, Neves KAL, Pena HF, Ortolani EL, et al. Seroprevalence of Toxoplasma gondii antibodies in captive wild mammals and birds in Brazil. J Zoo Wildl Med. 2010;41:572-4.

31. De Thoisy B, Demar M, Aznar C, Carme B. Ecologic correlates of Toxoplasma gondii exposure in free-ranging neotropical mammals. J Wildl Dis. 2003;39:456-9.

32. Ferreira DRA, Ribeiro VO, Laroque PO, Wagner PGC, Pinheiro Júnior JW, Silva $J C R$, et al. Risk factors associated with Toxoplasma gondii infection in captive Sapajus spp. Am J Primatol. 2015;77:558-62.

33. Costa DGC, Marvulo MFV, Silva JSA, Santana SC, Magalhães FJR, Filho CDFL, et al. Seroprevalence of Toxoplasma gondii in domestic and wild animals from the Fernando de Noronha, Brazil. J Parasitol. 2012;98:679-80

34. Santos PS, Albuquerque GR, da Silva VMF, Martin AR, Marvulo MFV, Souza SLP, et al. Seroprevalence of Toxoplasma gondii in free-living Amazon River dolphins (Inia geoffrensis) from central Amazon, Brazil. Vet Parasitol. 2011;183:171-3.

35. Mercier A, Ajzenberg D, Devillard S, Demar MP, De Thoisy B, Bonnabau H, et al. Human impact on genetic diversity of Toxoplasma gondii: example of the anthropized environment from French Guiana. Infect Gen Evol. 2011;11:1378-87.

36. Afonso E, Thulliez P, Gilot-Fromont E. Transmission of Toxoplasma gondii in an urban population of domestic cats (Felis catus). Int J Parasitol. 2006;36:1373-82.

37. Curry PS, Elkin BT, Campbell M, Nielsen K, Hutchins W, Ribble C, Kutz SJ. Filter-paper blood samples for ELISA detection of Brucella antibodies in caribou. J Wildl Dis. 2011:47:12-20.

38. Curry PS, Ribble C, Sears WC, Orsel K, Hutchins W, Godson D, et al. Blood collected on filter paper for wildlife serology: evaluating storage and temperature challenges of field collections. J Wildl Dis. 2014;50:308-21.

39. Aston EJ, Mayor P, Bowman DD, Mohammed HO, Liotta JL, Kwok O, Dubey JP. Use of filter papers to determine seroprevalence of Toxoplasma gondii among hunted ungulates in remote Peruvian Amazon. Int J Parasitol Parasites Wildl. 2014;3:15-9.

40. Elmore SA, Huyvaert KP, Bailey LL, Jared M, Alisauskas RT, Gajadhar AA Jenkins EJ. Toxoplasma gondii exposure in arctic-nesting geese: A multi-state occupancy framework and comparison of serological assays. Int J Parasitol Parasites Wildl. 2014;3:147-53.

41. Jakubek EB, Mattsson R, Mörner T, Mattsson JG, Gavier-Widén D. Potential application of serological tests on fluids from carcasses: detection of antibodies against Toxoplasma gondii and Sarcoptes scabiei in red foxes (Vulpes vulpes). Acta Vet Scand. 2012;54:13.

42. Maksimov P, Buschtöns S, Herrmann DC, Conraths FJ, Görlich K, Tenter AM, et al. Serological survey and risk factors for Toxoplasma gondii in domestic ducks and geese in Lower Saxony, Germany. Vet Parasitol. 2011;182:140-9.

43. Jordan CN, Kaur T, Koenen K, DeStefano S, Zajac AM, Lindsay DS. Prevalence of agglutinating antibodies to Toxoplasma gondii and Sarcocystis neurona in beavers (Castor canadensis) from Massachusetts. J Parasitol. 2005;91:1228-9.

44. Mercier A, Garba M, Bonnabau H, Kane M, Rossi JP, Dardé ML, Dobigny G. Toxoplasmosis seroprevalence in urban rodents: a survey in Niamey, Niger. Mem Inst Oswaldo Cruz. 2013:108:399-407.

45. IBGE. In: Demographic census of Rio de Janeiro. http://cod.ibge.gov.br/E4X. Accessed 12 Sept 2016.

46. Demographic density of districts of the city of Rio de Janeiro. In: Portal GeoRio. http://portalgeo.rio.rj.gov.br/armazenzinho/web/imagens/09 Densidade_demografica_2010.pdf. Accessed 12 Sept 2016.

47. Armazém de dados. In: Population dynamics by administrative region. http://www.armazemdedados.rio.rj.gov.br/arquivos/2965_dinam_pop_ra.JPG. Accessed 12 Sept 2016.

48. Desmonts $\mathrm{G}$, Remington JS. Direct agglutination test for diagnosis of Toxoplasma infection: method for increasing sensitivity and specificity. J Clin Microbiol. 1980;11:562-8.

49. R Core Team. R: A language and environment for statistical computing. Vienna: R Foundation for Statistical Computing. https://www.R-project.org/. Accessed 12 Sept 2016.

50. Nogami S, Kamata H, Maruyama S, Furuya H, Inoue I. Preservation of feline anti-Toxoplasma gondii antibody activity using blood absorbed on filter paper stored under different conditions. Res Vet Sci. 1992;52:387-8.

51. Barros RS, Menezes RC, Pereira SA, Figueiredo FB, Oliveira RVC, Nicolau JL, et al. Feline sporotrichosis: coinfection with Toxoplasma gondii, feline immunodeficiency virus and feline leukemia virus in cats from an endemic area in Brazil. Acta Sci Vet. 2015:43:1316.

52. Bastos BF, Brener B, Gershony L, Willi L, Labarthe N, Pereira C, Mendes-DeAlmeida F. Seroprevalence of Toxoplasma gondii (Nicole \& Manceaux, 1909) and retroviral status of client-owned pet cats (Felis catus, Linnaeus, 1758) in Rio de Janeiro, Brazil. Rev Inst Med Trop Sao Paulo. 2014;56:201-3.

53. Mendes-de-Almeida F, Labarthe N, Guerreo J, Faria MCF, Branco AS, Pereira $C D$, et al. Follow-up of the health conditions of an urban colony of freeroaming cats (Felis catus Linnaeus, 1758) in the city of Rio de Janeiro, Brazil. Vet Parasitol. 2007;147:9-15.

54. Netto EG, Munhoz AD, Albuquerque GR, Lopes CW, Ferreira AMR. Ocorrência de gatos soropositivos para Toxoplasma gondii Nicolle e Manceaux, 1909 (Apicomplexa: Toxoplasmatinae) na cidade de Niterói, Rio de Janeiro. Rev Bras Parasitol Vet. 2003;12:145-9.

55. Cong W, Wei C, Qing-Feng M, Radu B, Isabelle V, Xing-Quan Z, Ai-Dong Q. Toxoplasma gondii, Dirofilaria immitis, feline immunodeficiency virus (FIV), and feline leukemia virus (FeLV) infections in stray and pet cats (Felis catus) in northwest China: co-infections and risk factors. Parasitol Res. 2015;115:217-23.

56. Afonso E, Thulliez P, Gilot-Fromont E. Local meteorological conditions, dynamics of seroconversion to Toxoplasma gondii in cats (Felis catus) and oocyst burden in a rural environment. Epidemiol Infect. 2010;138:1105-13.

57. Miró G, Montoya A, Jiménez S, Frisuelos C, Mateo M, Fuentes I. Prevalence of antibodies to Toxoplasma gondii and intestinal parasites in stray, farm and household cats in Spain. Vet Parasitol. 2004;126:249-55.

58. Gauss CBL, Almeria S, Ortuno A, Garcia F, Dubey JP. Seroprevalence of Toxoplasma gondii antibodies in domestic cats from Barcelona, Spain. J Parasitol. 2003;89:1067-8.

59. Dubey JP, Saville WJA, Stanek JF, Reed SM. Prevalence of Toxoplasma gondii antibodies in domestic cats from rural Ohio. J Parasitol. 2002;88:802-3.

60. Afonso E, Thulliez P, Pontier D, Gilot-Fromont E. Toxoplasmosis in prey species and consequences for prevalence in feral cats: not all prey species are equal. Parasitol. 2007:134:1963-71.

61. Afonso E, Lemoine M, Poulle ML, Ravat MC, Romand S, Thulliez P, et al. Spatial distribution of soil contamination by Toxoplasma gondii in relation to cat defecation behaviour in an urban area. Int J Parasitol. 2008;38:1017-23.

62. Turner DC, Bateson P. The domestic cat: the biology of its behaviour. Cambridge University Press; 2013. 
63. Afonso E, Germain E, Poulle ML, Ruette S, Devillard S, Say L, et al. Environmental determinants of spatial and temporal variations in the transmission of Toxoplasma gondii in its definitive hosts. Int J Parasitol Parasites Wildl. 2013;2:278-85.

64. Da Silva RC, Machado GP, de A Cruvinel TM, Cruvinel CA, Langoni H. Detection of antibodies to Toxoplasma gondii in wild animals in Brazil. J Venom Anim Toxins Incl Trop Dis. 2014;20:41.

65. Cañon-Franco WA, Yai LEO, Joppert AM, Souza CE, D'Auria SRN, Dubey JP, Gennari SM. Seroprevalence of Toxoplasma gondii antibodies in the rodent capybara (Hidrochoeris hidrochoeris) from Brazil. J Parasitol. 2003;89:850.

66. Vollaire MR, Radecki SV, Lappin MR. Seroprevalence of Toxoplasma gondii antibodies in clinically ill cats in the United States. Am J Vet Res. 2005;66:874-7.

67. Almería S, Calvete C, Pagés A, Gauss C, Dubey JP. Factors affecting the seroprevalence of Toxoplasma gondii infection in wild rabbits (Oryctolagus cuniculus) from Spain. Vet Parasitol. 2004;123:265-70.

68. Beral M, Rossi S, Aubert D, Gasqui P, Terrier ME, Klein F, et al. Environmental factors associated with the seroprevalence of Toxoplasma gondii in wild boars (Sus scrofa), France. EcoHealth. 2012;9:303-9.

69. Alerta-RIO. In: Annual report of precipitation in the city of Rio de Janeiro - Report 001/2015. http://alertario.rio.rj.gov.br/upload/rel2014.pdf. Accessed 12 Sept 2016.

70. Daniels ME, Hogan J, Smith WA, Oates SC, Miller MA, Hardin D, et al. Estimating environmental conditions affecting protozoal pathogen removal in surface water wetland systems using a multi-scale, model-based approach. Sci Total Environ. 2014;493:1036-46.

71. Hogan JN, Daniels ME, Watson FG, Oates SC, Miller MA, Conrad PA, et al. Hydrologic and vegetative removal of Cryptosporidium parvum, Giardia lamblia, and Toxoplasma gondii surrogate microspheres in coastal wetlands. Appl Env Microbiol. 2013;79:1859-65.

72. Shapiro K, Conrad PA, Mazet JA, Wallender WW, Miller WA, Largier JL. Effect of estuarine wetland degradation on transport of Toxoplasma gondi surrogates from land to sea. Appl Env Microbiol. 2010;76:6821-8.

73. Fayer R, Dubey JP, Lindsay DS. Zoonotic protozoa: from land to sea. Trends Parasitol. 2004;20:531-6.

74. Pena HFJ, Soares RM, Amaku M, Dubey JP, Gennari SM. Toxoplasma gondii infection in cats from Sao Paulo state, Brazil: seroprevalence, oocyst shedding, isolation in mice, and biologic and molecular characterization. Res Vet Sci. 2006;81:58-67.

75. Dubey JP, Navarro IT, Sreekumar C, Dahl E, Freire RL, Kawabata HH, et al. Toxoplasma gondii infections in cats from Paraná, Brazil: seroprevalence, tissue distribution, and biologic and genetic characterization of isolates. J Parasitol. 2004;90:721-6.

76. Silva JCR, Gennari SM, Ragozo AMA, Amajones VR, Magnabosco C, Yai LEO, et al. Prevalence of Toxoplasma gondii antibodies in sera of domestic cats from Guarulhos and São Paulo, Brazil. J Parasitol. 2002;88:419-20.

77. Agency Cl. The world factbook. Washington (D.C.): Central Intelligence Agency; 2016. https://www.cia.gov/library/publications/the-world-factbook/ geos/br.html. Accessed 8 Dec 2016.

\section{Submit your next manuscript to BioMed Central and we will help you at every step:}

- We accept pre-submission inquiries

- Our selector tool helps you to find the most relevant journal

- We provide round the clock customer support

- Convenient online submission

- Thorough peer review

- Inclusion in PubMed and all major indexing services

- Maximum visibility for your research

Submit your manuscript at www.biomedcentral.com/submit

) Biomed Central 